No 4078

Studia nad Autorytaryzmem i Totalitaryzmem 43, nr 4 Wrocław 2021

https://doi.org/10.19195/2300-7249.43.4.10

\author{
KATARZYNA LIŻYŃSKA \\ ORCID: 0000-0002-9666-1019 \\ Uniwersytet Wrocławski \\ katarzyna.lizynska@uwr.edu.pl
}

ANNA PŁOŃSKA

ORCID: 0000-0003-1191-7407

Uniwersytet Wrocławski

anna.plonska@uwr.edu.pl

\title{
Model orzecznictwa w sprawach o wykroczenia w Polsce Ludowej
}

Słowa kluczowe: autorytaryzm, prawo wykroczeń, wykroczenie, postępowanie w sprawach o wykroczenia, kolegia orzekające.

\section{MODEL OF JURISPRUDENCE IN PETTY OFFENCE CASES IN THE PEOPLE'S REPUBLIC OF POLAND}

\begin{abstract}
The authoritarian ideology that guided the authorities of the communist Polish state did not remain indifferent to the emerging model of jurisprudence in petty offence cases. Eliminating the possibility of court proceedings, the location of adjudicating boards in petty offence cases at national councils, the introduction of collegial jurisprudence exercised by the social factor, giving the jurisprudence an educational character, and abandoning it in favour of severe penalties implemented for hooligan petty offences - these are just some of the features that distinguish the jurisprudence model in petty offence cases in the People's Republic of Poland. The pursuit of the authorities to subordinate the individuals by, on the one hand, handing over the jurisprudence in petty offence cases into the hands of the people, and, on the other hand, filling the adjudication boards with members subordinate to the authority, did not bring independence in the decisions issued. It is evidenced, for example, by the excessive repressive adjudication boards judgments issued against participants of the political crisis of March 1968. The Authors present the development of the model of jurisprudence in petty offence cases in the controversial period of the communist regime.
\end{abstract}

Keywords: authoritarianism, petty offences law, petty offence, proceedings in petty offence cases, adjudication boards.

Studia nad Autorytaryzmem i Totalitaryzmem 43, nr 4, 2021

(C) for this edition by CNS 
Rozwój modelu orzecznictwa w sprawach o wykroczenia jest nierozerwalnie związany z ukształtowaniem się prawa o wykroczeniach (dalej: p.o.w.), którego zaczątek datuje się na moment odzyskania przez Polskę niepodległości w 1918 ro$\mathrm{ku}$, kiedy to rozpoczęły się szeroko zakrojone prace nad kodyfikacją węzłowych gałęzi rodzimego prawa ${ }^{1}$. W zakresie wykroczeń proces ten przebiegał pod znakiem ścierania się różnorodnych koncepcji teoretycznych, lecz największy wpływ na ostateczne rozwiązania ustawowe i praktykę funkcjonowania zawsze wywierały czynniki polityczne ${ }^{2}$.

Nie da się przedstawić modelu orzecznictwa karno-administracyjnego Polski Ludowej bez chociażby pobieżnego zaprezentowania modelu tego orzecznictwa od czasu powstania niepodległej Polski. Ścieranie modeli pozostałych po państwach zaborczych ${ }^{3}$ oraz fascynacje szybkim i bezpośrednim stosowaniem środków represji karnej przez organy administracji ${ }^{4}$ sprawiły, że już na początku uwidoczniły się tendencje ustawodawcy do przekazywania organom administracji obowiązku karania wykroczeń. Mimo że sama Konstytucja z $1921 \mathrm{roku}^{5}$ stała na stanowisku jednolitości prawa karnego, wskazując, że ,żadna ustawa nie może zamykać obywatelowi drogi sądowej dla dochodzenia krzywdy lub straty”6, a „od karnych orzeczeń władz administracyjnych zapadłych w drugiej instancji będzie przysługiwało stronom prawo odwołania się do właściwego sądu" , późniejsze decyzje ustawodawcy w zakresie rozpoznania spraw o wykroczenia, jak pokazuje historia, nie były zgodne z pierwotnymi założeniami.

Początkowo system koncepcji odpowiedzialności za wykroczenia funkcjonował bez zastrzeżeń. Kary miały być wymierzane przez sądy, organy administracji orzekały „zastępczo”, a ich rozstrzygnięcia na żądanie obywatela miały podlegać kontroli sądowej. Uchwalone 22 marca 1928 roku rozporządzenie Prezydenta RP o postępowaniu karno-administracyjnym ${ }^{8}$ w myśl założeń ustawy

1 A. Marek, Prawo wykroczeń (materialne i procesowe), Warszawa 2012, s. 8.

2 M. Łysko, Ewolucja polskiego systemu prawa wykroczeń w XX w., „Miscellanea Historico-Iuridica" 17, 2018, z. 1, s. 169.

${ }^{3}$ Po odzyskaniu przez Polskę niepodległości obowiązywały na jej terenie trzy systemy prawne: austriacki - typizujący wykroczenia kryminalne rozpoznawane przez sądy powiatowe i tak zwane wykroczenia policyjne rozpoznawane przez organy administracji; rosyjski, w którym sprawy o wykroczenia podlegały orzecznictwu sądowemu; oraz system niemiecki na terenach byłego zaboru pruskiego, traktujący wykroczenia jako drobniejsze przestępstwa, jednakże ze względu na mnogość spraw w tym zakresie orzecznictwo przekazane zostało organom administracji, zachowując przy tym warunkowy charakter kompetencji organów administracji i dopuszczając do orzekania przez sądy przy żądaniu strony skierowania sprawy na drogę sądową.

4 Tak: J. Jakubowska-Hara, K. Łucarz, [w:] Reforma prawa wykroczeń, t. 2, red. P. Daniluk, Warszawa 2020, s. 7.

5 Ustawa z dnia 17 marca 1921 roku Konstytucja Rzeczypospolitej Polskiej (Dz.U. Nr 44, poz. 267 ze zm.).

6 Art. 98 Konstytucji z 1921 roku.

7 Art. 72 Konstytucji z 1921 roku.

${ }^{8}$ Dz.U. Nr 38, poz. 365. 
zasadniczej powierzało zatem wykroczenia zagrożone karą nie wyższą niż grzywna w wysokości 3 tysięcy złotych i areszt do 3 miesięcy, niezależnie od kar dodatkowych, orzecznictwu władz administracyjnych. Zostały powołane powiatowe władze administracji ogólnej, które były podmiotami właściwymi do dochodzenia i karania sprawców wykroczeń. Postępowanie w sprawach o wykroczenia oparte zostało na szybkiej i prostej procedurze administracyjnej, a droga sądowa zapewniona została warunkowo, przy złożonym sprzeciwie od wydanego przez władze administracyjne orzeczenia.

Ze względu na przemiany społeczno-ustrojowe zachodzące w Polsce po II wojnie światowej zasadność dalszego obowiązywania p.o.w. jako aktu prawnego uchwalonego „w przedwojennych kapitalistycznych stosunkach” stanęło pod znakiem zapytania. Przyjęte w p.o.w. rozwiązania nie były bowiem wystarczające, aby w pełni zaspokoić nowe odmienne potrzeby związane $\mathrm{z}$ budowaniem ustroju socjalistycznego ${ }^{9}$.

Zauważalne stało się odchodzenie od kontroli sądowej orzecznictwa organów administracji. Dotyczy to zwłaszcza nowo tworzonych wykroczeń. Jednym z przejawów większej roli administracji nad sprawami z zakresu wykroczeń było coraz powszechniejsze posługiwanie się przez środowisko prawnicze terminem ,prawo karno-administracyjne”, używanym w miejsce określenia „prawo wykroczeń”, co miało podkreślać wzrastającą rolę aparatu administracji w rozstrzyganiu spraw o wykroczenia ${ }^{10}$. W ówczesnym piśmiennictwie uprawnienia jurysdykcyjne administracji uzasadniano między innymi tym, że podmioty te dogłębniej niż sądy znają zagadnienia administracyjne, a przyznane im prawo wymierzania kar może być lepiej wykorzystane jako narzędzie realizowania polityki administracyjnej ${ }^{11}$.

Stworzony w okresie międzywojennym system orzecznictwa karno-administracyjnego nie był dostosowany przede wszystkim do nowych warunków powstałych po reformie terenowego aparatu administracji państwowej. Krytykę tego systemu wiązano $\mathrm{z}$ umacnianiem się ideologii komunistycznej w ramach władzy państwowej czerpiącej wzorce $\mathrm{z}$ modelu przyjętego w Związku Radzieckim, który między innymi odrzucał koncepcję jednoosobowego rozstrzygania spraw o wykroczenia przez czynnik urzędniczy, a także powiązanie orzecznictwa w tych sprawach z wymiarem sprawiedliwości ${ }^{12}$.

Instytucjonalną zmianą w ustroju powszechnych organów orzekających w trybie karno-administracyjnym była wspomniana już reforma terenowych organów administracji państwowej z 1950 roku $^{13}$. Reforma ta przesądziła o zmianie modelu

9 Tak: M. Łysko, Udział przedstawicieli nauki w pracach nad kodyfikacją materialnego prawa wykroczeń w Polsce Ludowej, „Czasopismo Prawno-Historyczne” 2015, z. 1, s. 130.

10 M. Łysko, Prace nad kodyfikacja materialnego prawa wykroczeń w Polsce Ludowej (19601971), Białystok 2016, s.34.

11 J. Szumski, Środki penalne w polskim prawie wykroczeń, Lublin 1995, s. 39.

12 M. Łysko, Prace nad kodyfikacją..., s. 35.

13 Tak: J. Skupiński, Model polskiego prawa o wykroczeniach, Wrocław-Warszawa-Kraków-Gdańsk 1974, s. 99. 
orzecznictwa karno-administracyjnego. Ustawa z dnia 20 marca 1950 roku o terenowych organach jednolitej władzy państwowej ${ }^{14}$, znosząc dualizm administracji państwowej, sprawiła, że do końca 1972 roku pracą samorządów kierowały rady narodowe. Likwidacja samorządów wyeliminowała osobowość prawną społeczności lokalnych i pozbawiła je resztek własności komunalnych. Proces centralizacji oraz zniesienie samorządu były traktowane jako jedno $\mathrm{z}$ wielkich osiągnięć władzy ludowej. Działanie rad narodowych stawało się coraz bardziej scentralizowane i zbiurokratyzowane ${ }^{15}$. W związku z wprowadzonymi zmianami orzecznictwo w sprawach o wykroczenia zostało bowiem przekazane do kompetencji prezydiów powiatowych rad narodowych, a sprawy o wykroczenia rozpoznawane były przez pracowników prezydiów. Taki „urzędniczy” system orzeczniczy nie podobał się ówczesnej władzy, która popierała stworzenie orzecznictwa tak charakterystycznego dla komunizmu — kolegialnego, które miało być także wielostopniowe i powiązane $\mathrm{z}$ siecią rad narodowych ${ }^{16}$.

Urzeczywistnienie tych dążeń znalazło wyraz w ustawie z dnia 15 grudnia 1951 roku o orzecznictwie karno-administracyjnym ${ }^{17}$, która powołała do życia kolegia funkcjonujące przy prezydiach gminnych, miejskich, dzielnicowych i powiatowych rad narodowych. Początkowo kolegia nie miały specjalnej nazwy, gdyż dopiero w 1958 roku ustawodawca wprowadził określenie „kolegia karno-administracyjne”. Do tego czasu w języku potocznym nazywane były „kolegiami orzekającymi” ${ }^{18}$. Orzekały one w składzie przewodniczącego i dwóch członków kolegium, wyznaczonych przez przewodniczącego spośród członków zgromadzenia. W teorii podkreśla się, że reforma z 1951 roku wytyczyła nowy kierunek postępowania w sprawach o wykroczenia. Większą uwagę zwrócono na oddziaływanie wychowawcze, odchodząc od kierunku represyjnego ${ }^{19}$. Podstawową karą za wykroczenie była bowiem kara pracy poprawczej, której wymiar wynosił od 1 dnia do 3 miesięcy. Odstąpiono od wymierzania kary aresztu, a zamiast niej wymierzano karę pracy poprawczej, przyjmując, że jeden dzień pracy poprawczej jest równoważnikiem dnia aresztu. Drugą z możliwych kar była kara grzywny, jednak wymiar granicy kary grzywny, określony przez ustawę od 3 do

14 Dz.U. Nr 14, poz.130.

15 E. Sokalska, Przemiany strukturalne władz lokalnych w Polsce w II połowie XX w., ,Zeszyty Prawnicze UKSW" 11, 2011, nr 3, s. 313-314.

16 Tak: M. Zimmermann, Orzecznictwo karno-administracyjne, „Zagadnienia Karno-Administracyjne" 1965 , nr 4, s.7.

17 Dz. U. z 1958 r. Nr 77, poz. 396.

18 M. Łysko, Postępowanie nakazowe w sprawach o wykroczenia w Polsce Ludowej. Charakterystyka modelu orzecznictwa karno-administracyjnego Polski Ludowej, „Z Dziejów Prawa” 2019, nr 12 (20), s. 837. Nazwa „kolegia orzekające” została także użyta przez ustawodawcę w ustawie z dnia 25 września 1954 roku o reformie podziału administracyjnego wsi i powołaniu gromadzkich rad narodowych (Dz.U. Nr 43, poz. 191).

19 M. Bojarski, [w:] M. Bojarski, A. Płońska, Z. Świda, Podstawy materialnego i procesowego prawa o wykroczeniach, Wrocław 2012, s. 17. 
3000 złotych, uzależniony był od stopnia danego kolegium — przykładowo kolegia przy prezydiach gminnych oraz miejskich rad narodowych w miastach liczących do 10 tysięcy mieszkańców mogły orzec kary grzywny do 300 złotych lub karę pracy poprawczej do 6 dni. Konieczność orzeczenia wyższej kary wiązała się z przekazaniem sprawy do rozpoznania kolegium przy prezydium powiatowej rady narodowej.

Dokonana w grudniu 1951 roku reforma orzecznictwa karno-administracyjnego Polski Ludowej w zasadniczy sposób zmieniła ustrój organów orzekających, oparłszy się na koncepcji uspołecznienia i demokratyzacji orzecznictwa w sprawach o wykroczenia ${ }^{20}$. Niewyobrażalne w zmieniającej się sytuacji politycznej lat pięćdziesiątych, w szczycie stalinizmu, było pozostawienie orzecznictwa jednoosobowym organom administracyjnym. Z punktu widzenia prawidłowego rozwoju państwa budującego ustrój socjalistyczny utrzymanie takiego modelu orzecznictwa byłoby oczywistym anachronizmem ${ }^{21}$.

Reprezentujący czynnik społeczny członkowie kolegiów orzekających byli wybierani przez terenowe organy władzy państwowej — rady narodowe — spośród kandydatów zgłaszanych przez organizacje społeczne i polityczne ludu pracującego oraz zakłady pracy ${ }^{22}$. Listy kandydatów na członków kolegiów sporządzały prezydia rad narodowych, dzięki czemu organy administracji państwowej w pełni kontrolowały proces obsady personalnej kolegiów orzekających. W myśl zasady kolegialności sprawy o wykroczenia rozpoznawały, oparte na czynniku społecznym, trzyosobowe składy orzekające, podczas gdy kierujący pracą kolegium przewodniczący $\mathrm{z}$ racji zasiadania $\mathrm{w}$ prezydium rady narodowej miał reprezentować czynnik urzędniczy ${ }^{23}$. Utworzone przy prezydiach rad narodowych kolegia miały sprawować przede wszystkim funkcję wychowawczą, zadaniem zaś organów państwowych było społeczno-wychowawcze oddziaływanie na obywateli ${ }^{24}$. Zgodnie $\mathrm{z}$ ideą socjalizmu wprowadzono zasadę orzekania na rozprawie z udziałem przedstawicieli organizacji społecznych i kolektywów pracowniczych $^{25}$. Odwołania od orzeczeń i nakazów karnych rozpoznawane były przez kolegia przy prezydiach rad narodowych bezpośrednio wyższego stopnia. Kolegia szczebla wojewódzkiego zostały utworzone w związku z likwidacją sądowej kontroli orzecznictwa karno-administracyjnego i wprowadzeniem wzorowanej

${ }^{20}$ M. Łysko, Ksztaltowanie się ustroju kolegiów orzekających w Polsce Ludowej (19521956), „Czasopismo Prawno-Historyczne” 2021, z. 2, s. 249-250.

${ }^{21}$ Tak: J. Skupiński, op. cit., s. 99.

22 M. Łysko, Socjalistyczna reforma orzecznictwa karno-administracyjnego Polski Ludowej, [w:] Księga pamiątkowa dla uczczenia pamięci Profesor Krystyny Kamińskiej, red. A. Gaca, Toruń 2013, s. 322-323.

${ }^{23}$ K. Siarkiewicz, Ksztaltowanie się ustroju kolegiów, „Zagadnienia Wykroczeń” 1977, nr 4-5, s. 36 .

24 Tak: J. Skupiński, op. cit., s. 113.

25 A. Marek, [w:] System prawa karnego. Zagadnienia ogólne, t. 1, red. A. Marek, Warszawa 2010, s. 37. 
na procedurze administracyjnej instytucji odwołania do kolegium II instancji ${ }^{26}$. Zwierzchni nadzór nad orzecznictwem karno-administracyjnym, wyrażający się zwłaszcza w prawie wydawania wiążących kolegia wytycznych w zakresie polityki karnej, początkowo sprawował Prezes Rady Ministrów.

Ustawa z 15 grudnia 1951 roku, nawiązując do założeń ustrojowych państwa socjalistycznego, włączyła orzecznictwo karno-administracyjne do systemu organizacyjnego rad narodowych, co miało na celu przede wszystkim zagwarantowanie bezpośredniego wpływu organów przedstawicielskich na politykę karną w sprawach o wykroczenia. Orzecznictwo karno-administracyjne było bowiem traktowane jako narzędzie wspierające rady narodowe w realizacji ich zadań państwowych, jak również w zagwarantowaniu porządku społecznego na terenie ich działania ${ }^{27}$. Jak wskazuje Andrzej Marek, według ówczesnych poglądów na zadania administracji państwa socjalistycznego przyjęto, iż orzecznictwo karno-administracyjne ma być systemem środków wychowawczych, którymi posługuje się administracja przy realizacji nowych zadań ${ }^{28}$. Założeniem zmian wprowadzonych ustawą z 15 grudnia 1951 roku, przewidujących kolegialny tryb rozpatrywania spraw karno-administracyjnych, miało być wyrażenie dużego postępu w organizacji organów do spraw wykroczeń, analogicznego do dokonywanych w tym samym czasie reform ustrojowych i społecznych. Jednakże uzależnienie kolegiów od prezydiów rad narodowych wpłynęło negatywnie na funkcjonowanie orzecznictwa karno-administracyjnego $\mathrm{w}$ okresie stalinowskim ${ }^{29}$. Co więcej, instytucjonalne powiązanie kolegiów orzekających z systemem rad narodowych wykluczało ich niezależność. Wywierało bowiem wpływ na kształtowanie polityki karno-administracyjnej, czyniło niezawisłość członków kolegów stricte iluzoryczną, wreszcie — miało znaczenie dla aspektu organizacyjnego kolegiów. Zauważalne stało się osłabienie systemu, które łączyło się również z aspektem personalnym. Dopuszczenie tak zwanego czynnika społecznego do rozpoznawania spraw o wykroczenia oznaczało wszak, że członkowie kolegiów nie mieli wykształcenia prawniczego. Słabość kadrowa wyrażała się w braku czynnika fachowego, co przekładało się na obniżenie poziomu orzecznictwa, trudności z zaznajomieniem się z rozległymi przepisami prawno-administracyjnymi oraz problemy $\mathrm{z}$ radzeniem sobie $\mathrm{z}$ dużą liczbą spraw ${ }^{30}$.

Jak trafnie zauważa Marcin Łysko, reforma z 1951 roku została przeprowadzona na zbyt wczesnym etapie rozwoju społeczeństwa socjalistycznego, którego świadomość ulegała przemianom zbyt wolno w stosunku do wprowadzanych reform

${ }^{26}$ M. Łysko, Postępowanie nakazowe..., s. 837.

27 M. Siewierski, Prawo o wykroczeniach jako narzędzie realizacji zadań administracji, „Zagadnienia Wykroczeń” 1977, nr 4-5, s. 49.

28 A. Marek, Prawo wykroczeń..., s. 12.

29 M. Łysko, Ksztaltowanie się ustroju..., s. 273.

30 K. Łucarz, A. Muszyńska, Ewolucja polskiego systemu wykroczeń: przez autorytaryzm do demokracji. Część 1, „Studia nad Autorytaryzmem i Totalitaryzmem” 42, 2020, nr 4, s. 146-147. 
politycznych i ekonomicznych ${ }^{31}$. Szybko okazało się bowiem, że z uwagi na nieskuteczność kary pracy poprawczej przyjęty w 1951 roku system orzecznictwa w sprawach o wykroczenia wymaga przeprowadzenia kolejnej reformy. W związku z tym, na mocy ustawy z dnia 22 maja 1958 roku o zaostrzeniu odpowiedzialności karnej za chuligaństwo ${ }^{32}$, upoważniono kolegia karno-administracyjne do wymierzania kary aresztu za taksatywnie wymienione w ustawie wykroczenia o charakterze chuligańskim. Istotne znaczenie miała również nowelizacja ustawy $\mathrm{z}$ dnia 2 grudnia 1958 roku o orzecznictwie karno-administracyjnym ${ }^{33}$, na mocy której zniesiono karę pracy poprawczej, przywrócono kompetencję kolegiów do wymierzania kary aresztu za wskazane w niej wykroczenia, a także upoważniono kolegia do wymierzania zastępczej kary aresztu w przypadkach nieuiszczenia kary grzywny. Tym samym przywrócono instytucję żądania skierowania sprawy na drogę sądową ${ }^{34}$.

W wyniku reformy systemowej z 1958 roku nastąpiło odejście od zasady obligatoryjnego tworzenia kolegiów w gromadach i osiedlach, podstawowym zaś ogniwem w strukturze organizacyjnej stały się kolegia szczebla powiatowego, które jako organy I instancji funkcjonowały przy prezydiach powiatowych, dzielnicowych oraz rad narodowych większych miast. Organem II instancji było kolegium przy prezydium wojewódzkiej rady narodowej. W celu podniesienia niskiego poziomu funkcjonowania kolegiów reforma ta wprowadziła w odniesieniu do przewodniczącego kolegium oraz jego zastępców wymóg posiadania wykształcenia prawniczego. Także przewodniczący poszczególnych składów orzekających w „miarę możliwości” winni być rekrutowani spośród osób z fachowymi kwalifikacjami ${ }^{35}$. Rozwiązania te $\mathrm{w}$ dużej mierze przyczyniły się do wyeliminowania występujących w okresie stalinowskim braków w organizacji kolegiów ${ }^{36}$.

Wyłaniający się na tle nowelizacji z 1958 obraz orzecznictwa karno-administracyjnego dalece odbiegał od tego, który kreowała ustawa z 1951 roku. Ustawodawca ze względów praktycznych wyraźnie odstąpił od założeń uwzględniających indywidualizację kary i szerokie stosowanie środków o charakterze wychowawczym. Wyznaczył kierunek bardziej represyjny, rozszerzając uprawnienia kolegiów do stosowania surowych środków karnych ${ }^{37}$.

Dalsze zmiany w modelu orzecznictwa w sprawach o wykroczenia zostały wprowadzone ustawą z dnia 17 czerwca 1966 roku o przekazaniu niektórych drobnych przestępstw jako wykroczeń do orzecznictwa karno-administracyjnego ${ }^{38}$.

31 M. Łysko, Ewolucja polskiego systemu..., s. 176.

32 Dz.U. Nr 34, poz. 152 ze zm.

33 Dz.U. Nr 77, poz. 396.

34 A. Marek, Prawo wykroczeń..., s. 13.

35 Tak: M. Łysko, Karanie uczestników wydarzeń marcowych z 1968 r. przez kolegia karno-administracyjne, „Krakowskie Studia z Historii Państwa i Prawa” 13, 2020, nr 1, s. 64; zob. też idem, Zasady obsady personalnej kolegiów karno-administracyjnych Polski Ludowej, „Miscellanea Historico-Iuridica" 12, 2013.

36 M. Łysko, Ksztaltowanie się ustroju..., s. 274.

37 K. Lucarz, A. Muszyńska, op. cit., s. 151.

38 Dz.U. Nr 23, poz. 149. 
Ten akt prawny zapoczątkował proces rozwarstwienia wykroczeń i różnicowania środków odpowiedzialności, znajdując pełny wyraz w ustawie z dnia 20 maja 1971 roku - Kodeks wykroczeń ${ }^{39}$. Nowelizacja dokonana w 1966 roku pogłębiła odejście od nadawania administracyjnego charakteru orzecznictwu kolegiów oraz zmierzała do stopniowego krystalizowania się poglądu, że prawo wykroczeń stanowi dziedzinę prawa karnego sensu largo, postępowanie zaś w sprawach o wykroczenia jest odmianą postępowania karnego ${ }^{40}$. Reforma z 1966 roku, mimo że dotyczyła głównie materialnego prawa wykroczeń, przyniosła również istotną zmianę w zakresie orzecznictwa kolegiów. Wprowadzono bowiem instytucję radcy do spraw kolegium karno-administracyjnego, którego zadaniem była obsługa organizacyjno-prawna i biurowa oraz wykonywanie innych funkcji związanych z pracami kolegium. Radcą mogła zostać jedynie osoba o wykształceniu prawniczym i było to pierwsze w historii kolegiów sformułowanie tak wysokich wymagań co do kwalifikacji zawodowych osób biorących udział w pracach kolegiów ${ }^{41}$. Poza przesunięciem do obszaru wykroczeń niektórych drobnych przestępstw i przekazaniem jurysdykcji w tych sprawach kolegiom wskazana ustawa wprowadziła daleko idące zmiany w dziedzinie materialnego oraz procesowego prawa karno-administracyjnego, które w pewnym sensie wytyczyły nowy kierunek polityki karnej w omawianej dziedzinie prawa ${ }^{42}$.

Początkowy okres Polski Ludowej nie przyniósł większych zmian w zakresie orzecznictwa w sprawach o wykroczenia, jednak zmiany ustrojowe narzucały konieczność pilnego dostosowania orzecznictwa karno-administracyjnego do nowego ładu. Podsumowanie ewolucji prawa wykroczeń, jak również modelu orzecznictwa w tym zakresie w PRL stanowiła kodyfikacja z 20 maja 1971 roku $^{43}$. Uchwalono wówczas kodeks wykroczeń, kodeks postępowania w sprawach o wykroczenia oraz ustawę o ustroju kolegiów do spraw wykroczeń, które opierały się na założeniu odrzucającym karno-administracyjny charakter orzecznictwa w sprawach o wykroczenia ${ }^{44}$. Wprawdzie nadal w sprawach o wykroczenia orzekały kolegia, ale już nie „karno-administracyjne”, lecz „do spraw wykroczeń”.

Tadeusz Bojarski oceniał owo zerwanie z ,administracyjnością” jako początek tendencji do „usądowienia” polskiego prawa wykroczeń. Postępowanie w sprawach o wykroczenia opierało się bowiem w szerokim zakresie na zasadach procesu karnego z prawem żądania wejścia na drogę sądowąa ${ }^{45}$. Postulaty koniecznych reform

39 A. Marek, Prawo wykroczeń..., s. 14.

40 A. Marek, [w:] System prawa..., s. 38.

41 J. Skupiński, op. cit., s. 150.

42 K. Łucarz, A. Muszyńska, op. cit., s. 152.

43 A. Marek, Prawo wykroczeń..., s. 14.

44 A. Marek, Niedokończona reforma prawa wykroczeń, [w:] Teoretyczne i praktyczne problemy wspótczesnego prawa karnego. Księga Jubileuszowa dedykowana Profesorowi Tadeuszowi Bojarskiemu, red. A. Michalska-Warias, I. Nowikowski, J. Piórkowska-Flieger, Lublin 2011, s. 663.

45 T. Bojarski, Z problematyki form postepowania w sprawach o wykroczenia, [w:] Problemy wymiaru sprawiedliwości karnej. Księga Jubileuszowa Profesora Jana Skupińskiego, red. A. Błachnio-Parzych et al., Warszawa 2013, s. 666. 
w czasach PRL wiązały się z koniecznością poddawania orzecznictwa w sprawach o wykroczenia kontroli sądowej. W szczególności chodziło w nich o rozszerzenie kontroli sądowej, którą kodeks postępowania w sprawach o wykroczenia (dalej: k.p.w.) z 1971 roku ograniczył do zasadniczych kar aresztu i ograniczenia wolności. Według art. 86 k.p.w. z 1971 roku od orzeczeń kolegium I instancji zasadniczej kary aresztu lub kary ograniczenia wolności uprawnieni do wnoszenia odwołań mieli prawo złożyć środek zaskarżania w postaci żądania skierowania sprawy na drogę postępowania sądowego. Natomiast częściej orzekane zastępcze kary aresztu czy też zakaz prowadzenia pojazdów pozbawione były takiej kontroli46. Miały również miejsce poważne nadużycia w stosowanym często na podstawie zarządzeń ministra spraw wewnętrznych przyspieszonym trybie postępowania, w którym ze względu na klauzulę natychmiastowej wykonalności orzeczeń (art. 73 pkt 4 k.p.w.) ukarany był faktycznie pozbawiony gwarancji prawnych ${ }^{47}$. Przyjęte w art. 3 k.p.w. z 1971 roku założenia kodyfikacyjne podkreślały niezawisłość członków kolegiów do spraw wykroczeń w zakresie orzekania, sprawujących — paralelny do sądowego - tak zwany mały wymiar sprawiedliwości ${ }^{48}$.

Należy podkreślić, że przewidziane w k.p.w. z 1971 roku zasady i gwarancje prawne w dużym stopniu miały charakter fasadowy, co wynikało z instrumentalnego traktowania prawa wykroczeń i orzecznictwa w sprawach o wykroczenia przez ówczesne władze. W praktyce czynnik administracyjny kształtował składy kolegiów i tym samym wywierał istotny wpływ na ich orzecznictwo. Kolegia do spraw wykroczeń w zakresie stosowania prawa i polityki orzecznictwa podlegały bowiem nadzorowi Ministerstwa Spraw Wewnętrznych ${ }^{49}$.

Przyjęty dwuinstancyjny model kolegiów usytuowanych w I instancji przy terenowych organach administracji państwowej stopnia podstawowego, w II instancji natomiast przy terenowych organach administracji państwowej stopnia wojewódzkiego niewiele zmieniał. W przypadkach wymierzenia kary grzywny lub nagany przez kolegium I instancji środkiem prawnym było odwołanie do kolegium II instancji. W przypadkach zaś wymierzenia przez kolegium I instancji kary aresztu lub ograniczenia wolności w miejsce odwołania wchodziło żądanie skierowania sprawy na drogę postępowania sądowego. $Z$ kolei uchylanie prawomocnych rozstrzygnięć kolegiów zostało powierzone komisjom orzecznictwa w sprawach o wykroczenia, które początkowo były usytuowane przy prezydiach wojewódzkich rad narodowych, a później przy wojewodach ${ }^{50}$. Przyjęte w k.p.w. rozwiązania utrzymywały jednak w praktycznie niezmienionej formie model orzecznictwa w sprawach o wykroczenia — orzecznictwo w tym zakresie nadal

46 A. Marek, Kierunki postulowanych zmian prawa wykroczeń, „Państwo i Prawo” 1987, z. 2, s. $28 \mathrm{n}$.

47 A. Marek, Niedokończona reforma..., s. 664.

48 M. Siewierski, Model postepowania w sprawach o wykroczenia w projekcie nowego kodeksu, „Zagadnienia Karno-Administracyjne” 1969, nr 2, s. 26.

49 A. Marek, [w:] System prawa..., s. 39.

50 P. Daniluk, [w:] Reforma..., s. 13. 
było podporządkowane resortowi spraw wewnętrznych, a z racji dominującej pozycji tego resortu $\mathrm{w}$ strukturze organów państwowych wszelkie postulaty zmian zmierzających do osłabienia zależności kolegiów od aparatu spraw wewnętrznych nie miały racji bytu ${ }^{51}$.

Reasumując zawarte w tym artykule rozważania, należy wskazać, że ustawodawca przez cały okres funkcjonowania reżimu komunistycznego w kwestii wykroczeń konsekwentnie realizował założenia leżące u podstaw jego socjalistycznego modelu wzorowanego na ustawodawstwie i doświadczeniach Związku Radzieckiego ${ }^{52}$. „Odsądowienie” orzecznictwa w sprawach o wykroczenia, dostosowanie go do systemu rad narodowych i ich organów, wprowadzenie orzecznictwa kolegialnego sprawowanego przez czynnik społeczny, abstrahując od jego przygotowania $\mathrm{w}$ zakresie prowadzenia spraw o wykroczenia, początkowe wpajanie społeczeństwu wychowawczego charakteru kar z przejściem do nadmiernej represyjności - to przykłady dostosowywania modelu orzecznictwa w sprawach o wykroczenia do zmieniającej się sytuacji politycznej. Lansowane w ówczesnych latach poglądy doktryny radzieckiej, jakoby ,administracja winna wychowywać obywateli w duchu przestrzegania ustaw, zasad współżycia społecznego i wzajemnej pomocy” 53 , a następnie zasady ,jak najszybciej karać" ${ }^{54}$ oraz „rozwiązywania wszystkich zagadnień przy pomocy surowej represji" ${ }^{55}$ natychmiast znajdowały odzwierciedlenie w rzeczywistości PRL.

Niedemokratyczny porządek autorytarny, który przyświecał komunistycznej władzy Polski Ludowej, miał także wpływ na kształtowanie się modelu orzecznictwa w sprawach o wykroczenia. Przejawiało się to w szczególności w dążeniu do podporządkowania jednostki przez odejście od rozstrzygnięcia sprawy na drodze sądowej i oddanie orzecznictwa w sprawach o wykroczenia w ręce ludu, przy jednoczesnym obsadzeniu kolegiów członkami podporządkowanymi ówczesnej władzy. Nie można dostrzec istotnych zmian w modelu orzecznictwa w sprawach o wykroczenia aż do czasu obalenia komunizmu i zakończenia funkcjonowania PRL. Co prawda już po wejściu w życie 1 stycznia 1972 roku prawa wykroczeń wysuwano coraz więcej krytycznych uwag odnośnie do modelu orzecznictwa w sprawach o wykroczenia, odcięcia tego orzecznictwa od resortu spraw wewnętrznych i przeniesienia go pod zwierzchnictwo resortu sprawiedliwości, jednak zauważalne zmiany stały się możliwe dopiero po zmianie ustrojowej, w wyniku której Rzeczpospolita Polska stała się demokratycznym państwem prawa. Już

51 M. Łysko, Projekt ustawy o ustroju kolegiów do spraw wykroczeń z 1970 r. w ocenie uczestników dyskusji społecznej, „Miscellanea Historico-Iuridica” 15, 2016, z. 1, s. 199.

${ }^{52}$ M. Łysko, Przełom roku 1956 w Polsce a orzecznictwo karno-administracyjne, „Zeszyty Prawnicze UKSW"11, 2011, nr 4, s. 277.

53 Ibidem, s. 279.

54 Z. Orłowski, O pracy kolegiów orzekających w kampanii obowiązowych dostaw, „Poradnik dla Kolegiów Orzekających” 1956, nr 1, s. 5-6.

55 Uzasadnienie projektu ,prawa karno-administracyjnego”, IPN BU MSW II 4, s. 248. 
na mocy ustawy z dnia 29 maja 1989 roku o zmianie niektórych przepisów prawa karnego i prawa o wykroczeniach ${ }^{56}$ zniesiona została powszechnie krytykowana natychmiastowa wykonalność orzeczeń w postępowaniu przyśpieszonym (art. 73 pkt 3 k.p.w. z 1971 roku). Kolejna ważna zmiana nastąpiła na mocy ustawy nowelizacyjnej z 8 czerwca 1990 roku $^{57}$, która zniosła nadzór zwierzchni ministra spraw wewnętrznych nad orzecznictwem kolegiów do spraw wykroczeń, odrywając je od struktury administracyjnej i umieszczając je przy sądach rejonowych ${ }^{58}$. Natomiast zmiany dokonane przez ustawę zasadniczą z dnia 2 kwietnia 1997 roku $^{59}$ przyniosły całkowite ,usądowienie” orzecznictwa w sprawach o wykroczenia.

\section{Bibliografia}

Bojarski M., [w:] M. Bojarski, A. Płońska, Z. Świda, Podstawy materialnego i procesowego prawa o wykroczeniach, Wrocław 2012.

Bojarski T., Z problematyki form postępowania w sprawach o wykroczenia, [w:] Problemy wymiaru sprawiedliwości karnej. Księga Jubileuszowa Profesora Jana Skupińskiego, red. A. Błachnio-Parzych, J. Jakubowska-Hara, J. Kosonoga, H. Kuczyńska, Warszawa 2013.

Daniluk P., [w:] Reforma prawa wykroczeń, t. 2, red. P. Daniluk, Warszawa 2020.

Jakubowska-Hara J., Łucarz K., [w:] Reforma prawa wykroczeń, t. 2, red. P. Daniluk, Warszawa 2020.

Łucarz K., Muszyńska A., Ewolucja polskiego systemu wykroczeń: przez autorytaryzm do demokracji. Część 1, „Studia nad Autorytaryzmem i Totalitaryzmem” 42, 2020, nr 4.

Łysko M., Ewolucja polskiego systemu prawa wykroczeń w XX w., „Miscellanea Historico-Iuridica” 17, 2018, z. 1.

Łysko M., Karanie uczestników wydarzeń marcowych z 1968 r. przez kolegia karno-administracyj$n e$, ,Krakowskie Studia z Historii Państwa i Prawa” 13, 2020, nr 1.

Łysko M., Ksztaltowanie się ustroju kolegiów orzekajacych w Polsce Ludowej (1952-1956), „Czasopismo Prawno-Historyczne” 2021, z. 2.

Łysko M., Postępowanie nakazowe w sprawach o wykroczenia w Polsce Ludowej. Charakterystyka modelu orzecznictwa karno-administracyjnego Polski Ludowej, „Z Dziejów Prawa” 2019, nr 12 (20).

Łysko M., Prace nad kodyfikacja materialnego prawa wykroczeń w Polsce Ludowej (1960-1971), Białystok 2016.

Łysko M., Projekt ustawy o ustroju kolegiów do spraw wykroczeń z 1970 r. w ocenie uczestników dyskusji społecznej, „Miscellanea Historico-Iuridica” 15, 2016, z. 1.

Łysko M., Przełom roku 1956 w Polsce a orzecznictwo karno-administracyjne, „Zeszyty Prawnicze UKSW" 11, 2011, nr 4.

Łysko M., Socjalistyczna reforma orzecznictwa karno-administracyjnego Polski Ludowej, [w:] Księga pamiątkowa dla uczczenia pamięci Profesor Krystyny Kamińskiej, red. A. Gaca, Toruń 2013.

Łysko M., Udziat przedstawicieli nauki w pracach nad kodyfikacja materialnego prawa wykroczeń w Polsce Ludowej, „Czasopismo Prawo-Historyczne” 2015, z. 1.

56 Dz.U. Nr 34, poz. 180.

57 Dz.U. Nr 43, poz. 251.

58 A. Marek, Niedokończona reforma..., s. 665-666.

59 Dz.U. Nr 78, poz. 483. 
Łysko M., Zasady obsady personalnej kolegiów karno-administracyjnych Polski Ludowej, „Miscellanea Historico-Iuridica” 12, 2013.

Marek A., Kierunki postulowanych zmian prawa wykroczeń, „Państwo i Prawo” 1987, z. 2.

Marek A., Niedokończona reforma prawa wykroczeń, [w:] Teoretyczne i praktyczne problemy wspótczesnego prawa karnego. Księga Jubileuszowa dedykowana Profesorowi Tadeuszowi Bojarskiemu, red. A. Michalska-Warias, I. Nowikowski, J. Piórkowska-Flieger, Lublin 2011.

Marek A., Prawo wykroczeń (materialne i procesowe), Warszawa 2012.

Orłowski Z., O pracy kolegiów orzekajacych w kampanii obowiązkowych dostaw, „Poradnik dla Kolegiów Orzekających"1956, nr 1.

Siarkiewicz K., Ksztaltowanie się ustroju kolegiów, „Zagadnienia Wykroczeń” 1977, nr 4-5.

Siewierski M., Model postepowania w sprawach o wykroczenia w projekcie nowego kodeksu, „Zagadnienia Karno-Administracyjne" 1969, nr 2.

Siewierski M., Prawo o wykroczeniach jako narzędzie realizacji zadań administracji, „Zagadnienia Wykroczeń" 1977, nr 4-5.

Skupiński J., Model polskiego prawa o wykroczeniach, Wrocław-Warszawa-Kraków-Gdańsk 1974.

Sokalska E., Przemiany strukturalne władz lokalnych w Polsce w II połowie XX w., „Zeszyty Prawnicze UKSW" 11, 2011, nr 3.

System prawa karnego. Zagadnienia ogólne, t. 1, red. A. Marek, Warszawa 2010.

Szumski J., Środki penalne w polskim prawie wykroczeń, Lublin 1995.

Zimmermann M., Orzecznictwo karno-administracyjne, „Zagadnienia Karno-Administracyjne” 1965, nr 4. 